\title{
Study on the Promotion of Music Education to Medical Humanistic Concepts and its Application in Practical Teaching
}

\author{
Tongtong Zhou \\ Jining Medical College, Jining 272067 \\ E-mail:65256482@qq.com
}

\begin{abstract}
Keywords: Music; humanistic concept; practical teaching; innovation and development; medical colleges and universities

Abstract: With the development of medical and health services in China, the requirements for the quality of doctors and the humanistic concept are becoming higher and higher, and students in medical colleges and universities should pay more attention to the promotion of humanistic concept accomplishment. Medical colleges should take the quality education and humanistic ideas as the important goal of cultivating and bringing up college students. Medical career is a brilliant profession. In order to promote college students to smoothly invest in the medical career, it is the key to enhance students' medical humanistic ideas. The current medical education, through the music education to improve the students' love for life, is full of enthusiasm to work, to lay a foundation for students to better engage in medical work. Starting from the significance of music education to enhance the concept of medical humanities, this paper explores in detail the concrete practice of music in the process of medical education in colleges and universities.
\end{abstract}

Music is based on life practice. It is an artistic form of expressing human emotional life through singing. Music teaching can purify our mind, improve our interest and promote our pursuit of ideal. The medical college promotes the students' humanistic quality through the music teaching, promotes the students' bright and positive treatment of the future medical work, exerts the potential of the students, promotes the subjective initiative, and keeps a good state of mind and work enthusiasm in the special occupational environment of medical service. A qualified medical worker lays a solid foundation. This paper focuses on the practice and application of medical teaching to improve students' humanistic accomplishment through music teaching.

\section{Medical Humanistic Concepts}

Medical humanistic concept is a professional ethics and comprehensive quality that a doctor must have. It requires a doctor to treat patients as a goal, have a noble professional ethics, care and pay attention to the patient wholeheartedly, respect life, respect the patient, and serve the patient from the heart of the heart. The humanistic idea of the doctor is to take the patient as the starting point, not the 
disease as the starting point, to feel the patient's feeling, to understand the patient's pain and to solve the trouble for the patient. For example, doctors do surgery, many patients are given red packets, and very popular, so that not to give red packets, doctors do not do a good operation, this doctor has no professional integrity, not to talk about the humanities. In order to relieve the pain of the patient, in order to relieve the pain of the patient, the doctor can help the patient to relieve the pain, disperse the attention, and encourage the patient to fight with the disease.

\section{The Significance of Music to Enhance the Humanistic Concept of Medical Students}

\subsection{Improving the aesthetic taste of students}

Sincerity and beautiful mind are essential qualities for medical students. Music teaching helps to improve students' aesthetic taste and cultivate their noble moral sentiments. One of the remarkable features of music is to purify our mind, and the beautiful music can arouse the resonance of our mind, and to inspire and inspire us to pursue the beautiful things. In class, the music of different types and different themes can let the students immerse in different mood, feel the wonderful melody of music, promote the purification of our mind, and deepen the students' understanding of "true, good and beautiful". A lot of sound music can arouse the resonance of our mind and inspire us to pursue good things. For example, the song of "the heart of gratitude" is a classic song. Every time we hear it, it makes us understand how to be grateful and how to treat life sincerely ${ }^{[1]}$.

\subsection{Music can cultivate the noble moral sentiment of students}

Medical students must have noble moral sentiment, medical profession is a special industry, doctors contact patients every day, see the patient's life and death, the main duty of the doctor is to be responsible for the health of the patient, which requires the doctor to have a very high sense of responsibility, good heart state, and the attitude of treating patients consistently. At the same time, with a sober mind, any depravity and corruption are the blasphemy of the doctor's sacred profession, so as a future medical post, college students must improve their moral qualities and cultivate their moral sentiments, such as perseverance, courage, sincerity and kindness, while the music is just right. It is the catalyst and adhesive for the above ideological and moral quality. Music is derived from life. In the process of continuous life practice, people express some positive emotions and joyful mood through music. Therefore, music teaching can effectively improve the students' Ideological and moral quality ${ }^{[1]}$.

\subsection{Music teaching can promote communication among students and enhance mutual help and cooperation}

Mutual assistance is the ability of a doctor. We all know that in the operation room, the coordination between doctors is very important. Each time the knife needs to be very accurate, otherwise the patient will have a life danger, which requires the whole operation team to cooperate sincerely and work together. In addition, doctors in the process of patient care, in fact, a very important step is the process of communication, through language communication to understand the condition, the right medicine, the hospital nurses in the process of caring for patients also need to exchange and cooperate with each other. Music itself is through the form of music to convey people's thoughts and feelings, this transmission of feelings can also be mutual exchange and interaction, such as the expression of music, singing, singing, chorus, and so on, to the perfect interpretation of the content of the music to be expressed, and the need for the two or more common interpretation of music, and all of the music. The input of the body and mind makes the mutual emotional exchange 
sublimate, so as to achieve the best effect of music, which is the main content of the music promotion and the promotion of mutual assistance ${ }^{[2]}$.

\section{Improving Medical Students' Humanistic Quality through Music Practice Teaching}

\subsection{Improving musical accomplishment and enhancing the comprehensive quality of medical students}

Medical colleges should enhance the comprehensive quality of medical students through music education. First, patriotic spirit should be raised through patriotic songs. In the process of music teaching, patriotic songs are taught to stimulate students' patriotic enthusiasm and enhance their dedication $^{[3]}$. For example, "singing the motherland", "we serve as soldiers" and so on. Secondly, through the music teaching to improve the students' Ideological and moral quality, such as "the Volunteer March", through the national anthem, stimulate the students' spirit of initiative, infection and encouragement of students to strive to work hard, to improve their ideological quality. Finally, through the music teaching to improve the students' aesthetic concept, such as "devotion of love", "the road of heaven", and so on, through this kind of music teaching, improve the students' understanding of love, the pursuit of beauty, and promote the improvement of their ideological and moral qualities. Music plays an important role in the improvement of College Students' comprehensive quality. It has great significance for their future medical posts, dedication, dedication and selfless dedication ${ }^{[4]}$.

\subsection{Improving the perception of medical students through learning music}

Through music teaching, students' perception ability can be improved. The doctor's work needs to be exposed to different patients and patients, to fully feel the sufferings of the patient, and to gradually improve his ability to diagnose the disease. This is with the cumulative experience of the doctor and the feelings of the patient's condition. Music learning, whether it is singing or dancing, or music appreciation, playing the musical instruments, is the most important thing. It is necessary to realize the connotation of music and the content of music expression through all aspects of perception, which is of great help to the cultivation of the cognitive ability of medical students ${ }^{[5]}$.

\subsection{Promoting communication and cooperation among students through music practice}

Music practice can promote communication among students, strengthen mutual help and cooperation, and enhance friendship among students. Mutual assistance, cooperation and mutual communication are important tasks for doctors. Medical institutions can carry out practical activities of music through various ways. For example, every year a large musical evening is held in schools, promoting mutual help and cooperation among students through solo, chorus, dance and other forms. Moreover, schools should regularly perform voluntary singing activities in kindergartens, factories and mines, and homes for the aged, so as to enhance communication and interaction and promote the improvement of students' humanistic quality ${ }^{[6]}$.

\section{Conclusion}

Music is an art form based on real life. Through music education and people-oriented, it promotes the psychological quality of college students, promotes mutual assistance and cooperation among students, promotes students' aesthetic concept, strengthens students' humanistic ideas, and has excellent psychological quality, ideological and moral quality and medical treatment for future 
students to go to medical posts. The foundation of virtue lays the foundation.

\section{Acknowledgement}

\section{Shandong Province Art Science Key Project.}

Special Subject of Medical Humanities Education Research in Jining Medical College

\section{References}

[1] Wang Jiaying. Exploration of the application of medical humanities to practical teaching in music education [J]. Drama House, 2017 (7): 233-233.

[2] Cheng Xiao. On the role of music education in improving the humanistic quality of medical students in Vocational Colleges and Countermeasures [J]. mass literature and art, 2018 (4).

[3] Wan Xiao Fang. Strengthening medical students' life and culture education to improve the effectiveness of medical humanities education. [J]. medical education research and practice, 2016, 24 (3): 394-397.

[4] Zhang Lina. On the application of humanistic quality education in student affairs of Medical College Counselors [J]. examination week, 2017 (25): 195-196.

[5] The predicament and Countermeasures for the cultivation of medical humanistic quality of Wang Min excellent doctor -- Taking the cultivation of humanistic quality in the excellent experimental class as an example [D]. Dalian Medical University, 2016.

[6] Tian Si Yu. The macro influence of music on medical colleges and Universities -- a brief analysis of the creation of music appreciation for the humanistic cultivation of students in medical colleges and universities [J]. northern music, 2017, 37 (2): 219-219. 